\title{
THE IMPACT OF 12 MONTHS TREATMENT WITH IVACAFTOR ON SCOTTISH PAEDIATRIC CYSTIC FIBROSIS PATIENTS WITH THE G551D MUTATION: A REVIEW
}

\begin{abstract}
Carol Dryden $^{\mathrm{a}}$, Jane Wilkinson ${ }^{\mathrm{b}}$, David Young ${ }^{\mathrm{c}}$, Richard John Brooker ${ }^{\mathrm{d}}$ on behalf of the Scottish Paediatric Cystic Fibrosis Managed Clinical Network
\end{abstract} (SPCFMCN)

${ }^{a}$ Corresponding author

Department of Paediatrics, Wishaw General Hospital, Netherton Street, Wishaw, UK, ML2 0DP. Tel: 01698366024 carol.dryden@lanarkshire.scot.nhs.uk

${ }^{\mathrm{b}}$ CF Unit, Royal Hospital for Children, Glasgow, UK

${ }^{c}$ Department of Mathematics and Statistics, University of Strathclyde, Glasgow, UK

d Department of Medical Paediatrics, Royal Aberdeen Children's Hospital, Aberdeen, UK

Key words:

Cystic fibrosis

Ivacaftor

G551D

p.Gly551Asp

Word count:

1208 (excluding abstract, table etc) 


\section{WHAT IS KNOWN ABOUT THIS TOPIC?}

- Ivacaftor is a new drug with a novel mode of action

- It is licensed for CF patients with specific genotypes

- Manufacturer-sponsored randomised controlled trials suggest a mean increase in $\mathrm{FEV}_{1}$ of $10.1-10.7 \%$

\section{WHAT THIS STUDY ADDS}

- In a "real life" setting we observed a mean increase in $\mathrm{FEV}_{1}$ of $7.1 \%$ at 1 year

- In the short term at least, ivacaftor appears to be safe and effective in Scottish paediatric CF patients $\geq 6$ years of age with the G551D mutation 


\begin{abstract}
We reviewed the impact of ivacaftor on Scottish paediatric cystic fibrosis (CF) patients $\geq 6$ years of age after 12 months of treatment. Statistically significant improvements in $\mathrm{FEV}_{1}$ and $\mathrm{BMI}$ and a reduction in sweat chloride, all comparable with previously published data [1-3] were observed. The findings also suggested reduced use of intravenous antibiotics and oral antibiotics. No significant adverse effects were observed but a possible association with cataract formation could not be excluded. This review suggests that, in the short term at least, ivacaftor is effective and safe in paediatric patients $\geq 6$ years of age with G551D.
\end{abstract}

\title{
BACKGROUND
}

The CFTR potentiator, ivacaftor, was granted a European license in July 2012 and became available to Scottish CF patients aged $\geq 6$ years with the G551D mutation in early 2013. Efficacy and safety data had come from two, manufacturer sponsored, randomised controlled trials $[1,2]$ with small patient numbers; 26 children aged $6-11$ years and 19 young people $12-17$ years received the drug.

As a new drug with a novel mode of action, it is important to monitor the outcomes of ivacaftor administration in children with CF post marketing. In Scotland there is a high prevalence of the G551D mutation (11.19\% compared to $5.7 \%$ in UK, data from CF Registry report 2014), and an established managed clinical network (SPCF MCN) that reduces clinical management variability through the development of agreed standards of care. These factors make Scotland particularly suitable for a review of real life outcomes.

\section{METHODS}

Retrospective data on $\mathrm{FEV}_{1}$, weight, height, sweat chloride, antibiotic courses, and adverse effects were collected from all Scottish clinics delivering paediatric CF care using a standard form. Data were anonymised and entered into an Excel spreadsheet for analysis. Percent predicted $\mathrm{FEV}_{1}$ was calculated using Global Lung Initiative (GLI) references. Standard deviation $(Z)$ scores were calculated for weight, height and BMI to adjust for normal growth by age and gender. The paired t-test was used to evaluate changes in mean values from baseline. Ethics approval was not necessary in accordance with guidance issued by the NHS Research Ethics Service.

\section{RESULTS}

$100 \%$ of data collection forms were returned. Twenty-seven children attending 11 clinics were identified. One patient was excluded from analysis because he was wholly non-compliant with treatment. He was a 15 year old boy with a background of mental health problems which impacted on his acceptance of all prescribed medications; there were no concerns about adverse effects. Of the remaining 26 children audited, 22 started treatment between January and March 2013, 1 started earlier on compassionate grounds, and 3 started later upon reaching their $6^{\text {th }}$ birthday. The children had been on ivacaftor an average of 17.0 months (range $12-22$ ) when their data were submitted, and commenced treatment at a median age of 9.3 years (range $6.0-14.6)$. There was a female preponderance $(69 \%)$. All children had at least one copy of the G551D mutation. The second gene was dF508 in 73\%. One child was homozygous for G551D. One child was chronically and two intermittently 
infected with Pseudomonas aeruginosa at baseline. Ninety-two percent of patients were pancreatic insufficient. Two children $(8 \%)$ had a diagnosis of CF liver disease as defined by best practice guidance.[4] None of the children had CF-related diabetes. Three children (12\%) were on nutritional supplements. Five (19\%) were on regular intravenous antibiotics (given at set intervals as part of care package at discretion of responsible clinician). Two children (8\%) had type I diabetes mellitus, one of whom also had hypothyroidism. There were no other significant comorbidities.

The pre and post treatment results for $\mathrm{FEV}_{1}$, growth parameters and sweat chloride compared to published data are displayed in Table 1. 
Table 1: Pre- and post- treatment data compared to published data

\begin{tabular}{|c|c|c|c|c|c|c|c|c|c|c|c|c|c|}
\hline & \multicolumn{4}{|c|}{ Scotland $(n=26)$} & \multicolumn{3}{|c|}{ Davies et al $(\mathrm{n}=26)$} & \multicolumn{3}{|c|}{ Ramsey et al $(\mathrm{n}=83)$} & \multicolumn{3}{|c|}{ Rowe et al $(\mathrm{n}=151)$} \\
\hline & Baseline & $\begin{array}{l}12 \\
\text { months }\end{array}$ & \begin{tabular}{|l|}
$\begin{array}{l}\text { Mean } \\
\text { change }\end{array}$ \\
\end{tabular} & $P$ value & Baseline & $\begin{array}{l}48 \\
\text { weeks }\end{array}$ & $\begin{array}{l}\text { Mean } \\
\text { change }\end{array}$ & Baseline & $\begin{array}{l}48 \\
\text { weeks }\end{array}$ & \begin{tabular}{|l|}
$\begin{array}{l}\text { Mean } \\
\text { change }\end{array}$ \\
\end{tabular} & Baseline & $\begin{array}{l}6 \\
\text { months }\end{array}$ & $\begin{array}{l}\text { Mean } \\
\text { change }\end{array}$ \\
\hline $\begin{array}{l}\text { FEV1 \% predicted } \\
\text { Mean } \\
\text { Range }\end{array}$ & $\begin{array}{l}85.1 \\
28.4- \\
107.5\end{array}$ & $\begin{array}{l}92.2 \\
45.1- \\
108.2\end{array}$ & 7.1 & $<0.001$ & $\begin{array}{l}84.7 \\
52.4- \\
133.8\end{array}$ & 95.4 & 10.7 & $\begin{array}{l}63.5 \\
37.3- \\
98.2\end{array}$ & 73.6 & 10.1 & 82.6 & 90.1 & 6.7 \\
\hline $\begin{array}{l}\text { Weight } \\
\text { Mean }(\mathrm{kg}) \\
\text { Range }\end{array}$ & $\begin{array}{l}32.2 \\
17.8-65.0\end{array}$ & $\begin{array}{l}39.0 \\
19.7- \\
86.1\end{array}$ & 6.8 & $<0.001$ & $\begin{array}{l}31.8 \\
18.8- \\
62.6\end{array}$ & & 5.9 & $\begin{array}{l}61.7 \\
30.2- \\
107.2\end{array}$ & 64.8 & 3.1 & 55.2 & 56 & 2.5 \\
\hline $\begin{array}{l}Z \text { score (mean) } \\
\text { Range }\end{array}$ & $\begin{array}{l}0.03 \\
-1.9-2.0\end{array}$ & $\begin{array}{l}0.48 \\
-1.8-2.2\end{array}$ & 0.45 & $<0.001$ & & & & & & & & & \\
\hline $\begin{array}{l}\text { Height } \\
Z \text { score } \\
\text { Range } \\
\end{array}$ & $\begin{array}{l}-0.11 \\
-2.0-2.1 \\
\end{array}$ & $\begin{array}{l}0.14 \\
-1.7-2.1\end{array}$ & 0.25 & $=0.009$ & & & & & & & & & \\
\hline $\begin{array}{l}\text { BMI } \\
\text { Mean }(\mathrm{kg} / \mathrm{m} 2) \\
\text { Range }\end{array}$ & $\begin{array}{l}17.2 \\
13.5-23.8\end{array}$ & $\begin{array}{l}18.7 \\
13.5- \\
26.5\end{array}$ & 1.5 & $<0.001$ & $\begin{array}{l}17.1 \\
14.2- \\
26.0\end{array}$ & & & $\begin{array}{l}21.7 \\
14.8- \\
38.9\end{array}$ & & & 21.3 & 21.7 & 0.8 \\
\hline $\begin{array}{l}Z \text { score (mean) } \\
\text { Range }\end{array}$ & $\begin{array}{l}0.15 \\
-1.5-2.2 \\
\end{array}$ & $\begin{array}{l}0.57 \\
-1.7-2.3 \\
\end{array}$ & 0.42 & $<0.001$ & $\begin{array}{l}0.09 \\
-1.5-2.1 \\
\end{array}$ & $0.4^{*}$ & & & & & & & \\
\hline $\begin{array}{l}\text { Sweat chloride } \\
(\mathbf{m m o l} / \mathbf{L})(\mathbf{n}=\mathbf{1 8}) \\
\text { Mean } \\
\text { Range }\end{array}$ & $\begin{array}{l}112.1 \\
90.5- \\
148.0\end{array}$ & $\begin{array}{l}47.6 \\
13.0- \\
73.0\end{array}$ & -64.5 & $<0.001$ & $\begin{array}{l}104.3 \\
54-128\end{array}$ & & -56 & $\begin{array}{l}100.4 \\
74.5- \\
128.0\end{array}$ & & -48.7 & 102.9 & 49.1 & -53.8 \\
\hline
\end{tabular}

*This is an approximation taken from a graph within the paper 
Three children were overweight at baseline and remained so. Three, who were of healthy weight at baseline, became overweight (as defined by the International Obesity Task Force).

Eighteen children had sweat chloride measured at baseline and on treatment. It remained $>60 \mathrm{mmol} / \mathrm{L}$ (diagnostic range for $\mathrm{CF}$ ) in 5 children $(28 \%$ ). Mean increases in $\mathrm{FEV}_{1}$ and BMI within this group were $4.2 \%$ and $1.52 \mathrm{~kg} / \mathrm{m}^{2}$ respectively.

The G551D homozygote was a 6 year old boy with an $\mathrm{FEV}_{1}$ of $98.1 \%$ predicted and a BMI of $15.7 \mathrm{~kg} / \mathrm{m}^{2}$ at baseline. These parameters were essentially unchanged after one year of treatment however sweat chloride fell from $106 \mathrm{mmol} / \mathrm{L}$ to $13 \mathrm{mmol} / \mathrm{L}$ which was the lowest measurement in the whole group.

Other clinically significant findings were: of the 5 children receiving regular IV antibiotics at baseline, 1 child was able to stop and 2 had the frequency reduced; 7 (27\%) required fewer courses of oral antibiotics for mild respiratory exacerbations; and $7(27 \%)$ were able to reduce their dose of pancreatic enzyme replacement therapy (PERT), a change that was overseen by a dietitian in all cases.

Possible adverse effects reported included transient headaches $(n=1)$, transient unilateral ear swelling $(\mathrm{n}=1)$, and non-visually significant cataracts with no clear cause, detected 2 - 3 months into treatment with ivacaftor in 2 out of the 12 patients who had ophthalmological screening examinations. Liver function tests were monitored regularly by all clinics with no clinically significant derangements observed.

\section{DISCUSSION}

The findings of this review of a Scottish paediatric population, in keeping with published data, show statistically significant improvements in $\mathrm{FEV}_{1}$ and $\mathrm{BMI}$, and a reduction in sweat chloride after 12 months treatment with ivacaftor. Similarly there were observed reductions in the number of courses of antibiotic therapy and PERT dose.

The mean absolute increase in $\mathrm{FEV}_{1}$ of $7.1 \%$ was lower than that reported in the randomised phase 3 trials (10.7\% for 6-11 year olds [1] and $11.4 \%$ for $12-17$ year olds

[2]) and patients aged $\geq 6$ years real-world outcomes being studied at Cork University Hospital [5] (10.26\%), but similar to the post approval evaluation of ivacaftor published by Rowe et al [3] (6.7\%). It is, perhaps, not surprising that our "real life" data are slightly less compelling than data gained from tightly controlled clinical trials. Factors that could contribute to the difference include reduced patient adherence to treatment, no exclusion criteria (inhaled hypertonic saline was not discontinued, 1 child had low baseline $\mathrm{FEV}_{1}$ of $30 \%$ and 1 had high baseline $\mathrm{FEV}_{1}>$ $105 \%$ ), and the use of different lung function reference equations for calculating percent predicted values. We used GLI references whereas the phase 3 trials used Knudson, and Rowe et al used Wang. 
The increase in weight and BMI observed in our population was similar to that reported by Davies et al [1] and one might expect Rowe's cohort to be similar at one year considering their 6 month data [3]. Three children in our group became overweight over the course of their year on ivacaftor. The adverse effects of being overweight/obese on long term general health for patients with $\mathrm{CF}$ are now becoming topical. The nutritional status of patients on ivacaftor will need to be monitored closely and dietetic advice tailored accordingly. Information from the All Wales Adult $\mathrm{CF}$ Centre [6] is reassuring and indicates that increase in weight is mainly fat free mass, but there are no comparative data for children and fat free mass data were not collected in this review.

No significant adverse effects were noted. The association of cataract formation and ivacaftor in animal models led 5 of the 11 Scottish clinics to perform eye screening during the review. It is unknown whether the 2 children with non-visually significant cataracts had them before or developed them during treatment. A formal recommendation to carry out baseline and follow up ophthalmological examinations for all paediatric patients initiating treatment with ivacaftor has now been added to the Summary of Product Characteristics by the manufacturer.

In conclusion, this review suggests that in the short term at least, ivacaftor is effective and safe in paediatric CF patients $\geq 6$ years of age with G551D in Scotland. Continued monitoring is required to inform on long term efficacy and safety.

\section{ACKNOWLEDGEMENTS}

The authors are grateful to medical and nursing colleagues from the following network Units for providing data:

Borders General Hospital, Crosshouse Hospital, Dumfries \& Galloway Royal Infirmary, Forth Valley Royal Infirmary, Ninewells Hospital, Raigmore Hospital, Royal Aberdeen Children's Hospital, Royal Alexandra Hospital, Royal Hospital for Children Glasgow, Royal Hospital for Sick Children Edinburgh, Victoria Hospital, Wishaw General Hospital

Thanks also to Mr Gregory Fearn, SPCFMCN Manager, for administrative support, and Mr Raymond Hamill, Corporate Research \& Development Manager NHS Lanarkshire, for providing guidance on research ethics requirements.

\section{COMPETING INTERESTS}

The authors report no conflicts of interest in relation to the preparation of this manuscript. Dr. Dryden reports personal fees from a Vertex Advisory Board meeting regarding a different drug i.e. outside the submitted work.

\section{FUNDING}

Not applicable. 


\section{CONTRIBUTORSHIP}

CD conceived the study, designed and distributed data collections forms, received and analysed data, and drafted the manuscript.

JW assisted with design of data collection forms, revised the manuscript critically for important intellectual content, and approved final version.

DY undertook statistical analyses and interpretation, and revised the manuscript critically for important intellectual content, and approved final version.

$\mathrm{RB}$ is the network lead. He assisted with communication between hospitals, contributed to methodology, revised the manuscript critically for important intellectual content, and approved final version.

\section{REFERENCE LIST}

1 Davies JC, Wainwright CE, Canny GJ, et al. Efficacy and safety of Ivacaftor in patients aged 6 to 11 years with cystic fibrosis with a G551D mutation. Am J Respir Crit Care Med 2013;187(11):1219-25.

2 Ramsey BW, Davies J, McElvaney G, et al. A CFTR potentiator in patients with cystic fibrosis and the G551D mutation. NEJM 2011;365(18):1663-72.

3 Rowe SM, Heltshe SL, Gonska T, et al. Clinical mechanism of the cystic fibrosis transmembrane conductance regulator potentiator Ivacaftor in G551D-mediated cystic fibrosis. Am J Respir Crit Care Med 2014;190(2):175-84.

4 Debray D, Kelly D, Houwen R, et al. Best practice guidance for the diagnosis and management of cystic fibrosis-associated liver disease. J Cyst Fibros 2011;10(Suppl 2):S29-36.

5 Ronan NJ, O'Callaghan D, Mooney G, et al. Clinical outcomes of Real-World Kalydeco (CORK) study-a prospective 12 month analysis addressing the impact of CFTR modulation on the cystic fibrosis lung [abstract]. J Cyst Fibros 2015;14(Suppl 1):S37.

6 Prosser A, Proud D, Guhaniyogi L, et al. Transformational care at the All Wales Adult CF Centre (AWACFC)-is ivacaftor making us fat? The impact of ivacaftor (Kalydeco) on body composition [abstract]. J Cyst Fibros 2015;14(Suppl 1):S129. 